\title{
Professor Retired, \\ But the University Kept Paying Her!
}

\author{
Dr. Jan Colbert, Columbus State University, USA
}

\begin{abstract}
Dr. Retha Schnell, an accounting professor, took advantage of an offer of an early retirement package from the University. In May, year 1, she chose the one year option to teach for half pay while simultaneously receiving retirement from the State University Retirement System. Dr. Schnell's time with the University came to an end in May, year 2 and she moved to another state. (Her State University Retirement System payments continued.) The professor's bank statements, received over the Labor Day holiday, year 2, showed a payment of the same amount as she had been receiving for salary in the previous year. Further investigation by Dr. Schnell and the University revealed that Dr. Schnell's former Department Head, former Dean, and two employees in Human Resources (HR) had authorized her to be paid for the next academic year (although she was retired).
\end{abstract}

The case focuses on internal control matters. Specifically, the operation of internal controls which permitted payroll to be paid to a former employee are addressed. The design of controls is adequate; two members of management and two HR employees authorized payment of payroll for a faculty member no longer working at the University. The matters in the case relate to the components and principles in COSO's internal control framework.

Keywords: COSO; Internal Control; Human Resources; Payroll

\section{LEARNING OBJECTIVES}

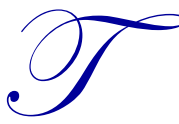

his case is intended to be used in upper level undergraduate courses such as Auditing and Assurance Services, Enterprise Risk Management, or Internal Control. The case might also be used in graduate courses in an MBA, Masters in Accountancy, or MPA (Masters in Public Administration) program.

1. The first learning objective is to illustrate through a real-life example the critical nature of the operation of internal controls.

2. The second learning objective is to suggest that holding management and employees accountable for their internal control responsibilities, through their annual evaluations, may help them to take their internal control responsibilities more seriously.

3. The third learning objective is to provide a real-life example to illustrate the components and principles of the COSO (Committee of Sponsoring Organizations of the Treadway Commission) framework of internal control.

\section{CASE SYNOPSIS}

A University, needing to cut spending, quickly formulated an early retirement program for faculty with sufficient years in the State University Retirement System. Dr. Retha Schnell, in the Department of Accounting, qualified, and opted to take advantage of the program. Part of the program was an option to teach either one year or two years at half pay.

In May of year 1, Dr. Schnell signed the paperwork for both the early retirement program with the University and the State University Retirement System. The option to teach for one year was selected. Dr. Schnell 
began drawing her State University Retirement System payments and in August of year 1, began teaching and drawing half of her former pay.

In May of year 2, Dr. Schnell finished teaching for the last time for the University and moved to another state, receiving her last paycheck, she thought. (The State University Retirement System payments continued.)

Over the Labor Day holiday of year 2, Dr. Schnell opened her bank statement to discover that an amount from the University which matched the amount she had been paid for half a month (the normal pay period) for the previous academic year had been deposited in her account. Further investigation by Dr. Schnell and the University unearthed the fact that her former Department Head had signed off on paying her for a second academic year, as had her former Dean. Further, two employees in Human Resources (who had the paperwork for her early retirement) had also signed off on paying the faculty member for a year in which she would not be working.

COSO (Committee of Sponsoring Organizations of the Treadway Commission; 2013) presents an integrated framework of internal control. Of its five components, control activities, monitoring, and control environment tie closely into this case. Authorizations by the Department Head, the Dean, and the two Human Resources employees are control activities; these authorizations should not have occurred. Monitoring of budgets after the payments to Dr. Schnell might have found the error. Finally, one of the 17 principles of COSO notes that part of the control environment component is enforcing accountability. Thus, the board of directors should be making sure that people are held responsible for their actions. Perhaps by having a part of each individual's annual evaluation cover how well the individual adhered to internal control policies and procedures would emphasize its importance.

\section{RESEARCH METHODS}

The author recently retired from a university and encountered a situation similar to that described here.

\section{CASE}

A regional university in the southeast had struggled with stagnant or slightly declining enrollments for a number of years. This situation, coupled with reduced funding from the state government, led to shortfalls in the university budget. Once the President announced plans to retire at his upcoming $70^{\text {th }}$ birthday, a new, younger, President, was hired.

In anticipation of the new President's arrival, the Board of Regents formulated and then quickly implemented plans to cut costs. The goal, developed and approved by the Board, was to reallocate (i.e., cut) $10 \%$ of the operating budget over two years. This amounted to approximately $\$ 25$ million. This pool of unrestricted funds would then be available to the new President to implement new programs. Since universities' primary expense is salaries, the planned cuts were to come by eliminating faculty and staff.

In order to implement the salary cuts, a program was quickly set up to encourage faculty with enough years to qualify for retirement ( 20 or more) to retire. If a faculty member chose to retire, the professor could also choose to teach part time for either one year or two years at the institution. The one or two years of teaching came with no research or service duties; the pay was at half the rate of the former salary. The option was made at the time of opting for 'early' retirement (the University's term); this election of zero, one, or two years could not later be changed.

A similar program was implemented for staff. With sufficient years in the State University Retirement System, staff could retire and receive a payout from the University. If a staff member was not qualified to retire, that person could leave the institution with a buyout package. The risk of staying at the University was impending layoff, with no package. There was no program for staff to work for period of time at a reduced rate.

To faculty and staff, information on these programs appeared to be hastily assembled and quickly disseminated. The deadlines for faculty to choose to retire or for staff to take the buyout package were within a few 
weeks of the announcement of the early retirement program. Anyone considering retirement was required to go to the offices of the State University Retirement System in the state capital, about an hour away. Paperwork for the State University Retirement System had to be completed prior to filling out the University paperwork. Thus, the process was time consuming, as well as having to be done in the very short time frame imposed by the University.

One professor, Retha Schnell, in the Department of Accounting, having 20 years credit in the State University Retirement System, decided to take advantage of the early retirement offer. She also elected to teach part time for one additional year.

Over Dr. Schnell's career, she had taught and researched in auditing and auditing related topics. These included internal control, COSO (Committee of Sponsoring Organizations of the Treadway Commission), corporate governance, internal auditing, fraud, and ethics. She frequently used real life examples in both her graduate and undergraduate classes.

In May of year 1, Dr. Schnell signed the State University Retirement System paperwork in the headquarters of the System in the state capital. She then completed the required documents at the University for early retirement and for one year of part time teaching. Her pay was to continue to be direct deposited, as the University mandated. The University paid all faculty, whether full-time or part-time, on a semi-monthly basis.

The University forms were approved by the Department Head of Accounting, Dr. Olivia Fenway. Next, the Dean of Business, Dr. Reggie Rimrod authorized the Dr. Schnell's early retirement by signing the same forms. From the College of Business, the forms were forwarded to Human Resources (HR). In HR, the same forms were signed by Cat Lind and David Prince. Ms. Lind was the HR employee assigned to track College of Business employees while Mr. Prince specialized in payroll issues.

In August of year 1, Dr. Schnell began teaching part time in the Fall semester and receiving half of her former salary (she also began receiving her retirement income from the State University Retirement System). This continued in the Spring semester of year 2.

In May of year 2, after teaching for one year, Dr. Schnell believed she received her final paycheck for teaching at the University. (She continued receiving her retirement check from the State University Retirement System.) Late in the Spring semester of year 2, friends at work gave Dr. Schnell a going away party, as she was moving out of state.

Over the Labor Day weekend of year 2, Dr. Schnell opened her hardcopy bank statement. She was shocked to discover a direct deposit from her former institution! The amount deposited was in the exact same amount for semi-monthly pay as she had been receiving in the academic year she had been teaching part time. The payment was for the period ending 08.15.year2.

Dr. Schnell's next step was to go to the University's online system to examine her earnings statements. The earnings statements reflected not just one, but two pay periods: 08.15.year 2 and 08.31.year2 (the latter was not reflected yet on the hardcopy bank statement). Dr. Schnell noted from the earnings statements that, besides earnings, taxes were impacted. Being an auditor, she was seriously concerned.

Dr. Schnell had dealt with HR at the University on unrelated issues in the past; she did not have confidence in the reliability of the Department. Thus, rather than email the Director of HR, she immediately went to the University website and scrutinized it for the email address of the Vice President (VP) of Financial Affairs. She also knew the Internal Auditor, a fellow CPA, so she obtained her email address as well. An email was fired off to the VP with a CC to the Internal Auditor with the subject line: No longer an employee; still getting paid!

Before 7 am the next morning (Labor Day, year 2), the VP replied. He had also forwarded the email to the new interim Director of HR, Jacob Stahl. As Jacob was a former MBA student of Dr. Schnell's in both Graduate Accounting and Graduate Statistics, the professor was delighted to learn that the MBA was the new interim Director 
of HR. Dr. Schnell had confidence that Jacob would sort out why she had been paid when she was not working for the institution.

Jacob replied to Dr. Schnell and explained the HR process. He also located a document which had prompted the paycheck to be generated.

In an email, Jacob explained to Dr. Schnell that in May of each year, each department head initiates a process to notify HR as to which faculty members will be with the department in the next academic year. A form, the Personnel Action Form (PAF), is filled out for each individual employee who will be working in the department. That PAF form is used by HR to prompt payroll to generate paychecks in the next academic year.

In May of year 2, Dr. Olivia Fenway had initiated a PAF for Dr. Schnell for Fall of year 2 and Spring of year 3. Dr. Fenway had done this even though Dr. Schell was no longer working for the University. Dr. Fenway signed the PAF on 04.14.year2 and forwarded the document to the Dean's office.

On 04.22.year2, Dean Rimrod signed the Dr. Schnell's PAF and forwarded it on to HR. In HR, Cat Lind and David Prince then both signed Dr. Schnell's PAF.

Both Dr. Fenway and Dean Rimrod knew Dr. Schnell very well personally and knew she had moved to another state and that she would no longer be teaching for the University. (In fact, Dr. Fenway had attended Dr. Schnell's going away party, off campus.) Dr. Schnell's early retirement paperwork, with the one year election that she had chosen to teach part time, was filed in HR.

Dean Rimrod retired in July of year 2. A new Dean took over the helm of the College of Business in August of year 2.

Once the PAF was filled out and signed by the appropriate individuals, it was forwarded to Payroll. Payroll then generated authorization for a direct deposit paychecks, starting with the 08.15.year2 paycheck and continuing with the 08.31.year2 paycheck. (Presumably, these would have continued through May of year 3 had Dr. Schnell not notified the University.)

After Dr. Schnell informed the University of its mistake, she was instructed to send a personal check for the amount of the two direct deposits to the University. She promptly did so. Once that was received, the University then corrected (removed) her online earnings statements for 08.15.year2 and 08.31.year2 from the online system.

As Dr. Schnell ruminated over the events leading to the incorrect payments, she recalled COSO's Internal Control - Integrated Framework (2013 and 1992), which she had taught many times in various courses. The definition of internal control presented in COSO notes that internal control is effected by people. In explaining the definition of internal control, COSO presents five components which make up internal control. One of those five components is control activities. Authorizations such as that which Dr. Fenway, Dean Rimrod, Ms. Lind, and Mr. Prince signed are a type of control activity.

\section{DISCUSSION QUESTIONS}

1. Who are the key players?

2. a. Who made the first error in signing the PAF?

b. Who made the second error in signing the PAF?

c. When the PAF got to HR, the two personnel there apparently simply signed the form. Prior to signing the form, what should they have done?

3. a. What is the definition of internal control, per COSO?

b. Give the five components of internal control, per COSO.

c. The last component of internal control is monitoring. Monitoring may include ongoing evaluations. An 
example of ongoing evaluations is managers comparing actual results to budget. For example, the Dean (manager) may compare the actual salary results to the budgeted amounts at the end of the semester. Would monitoring have found the pay mistake for Dr. Schnell?

4. a. Was the design of internal control, i.e., the authorizations on the PAF form, adequate?

b. Was the operation of the internal control of authorization on the PAF form adequate?

5. Should employee annual evaluations include criteria encompassing whether the employees have adhered to following internal controls? In this case, those evaluations would be those of Dr. Fenway, Dean Rimrod, Ms. Lind, and Mr. Prince. In developing your answer, be sure to read number 5. under Control Environment within the Components and Principles section (p. 6) at www.coso.org "Internal Control Integrated Framework Executive Summary" (2013).

\section{AUTHOR INFORMATION}

Dr. Jan Colbert is a Professor of Accounting at Columbus State University in Columbus, GA. Dr. Colbert has been active in the accounting profession, serving on the Kentucky State Board of Accountancy and on the AICPA Exams Team for the CPA exam. She has published over 100 articles on topics including corporate governance, internal control, ethics, auditing standards, and ethics. Dr. Colbert was presented with the AICPA Distinguished Achievement in Accounting Education Award in 2013. Her email is: colbert_janet@ columbusstate.edu.

\section{REFERENCES}

Committee of Sponsoring Organizations of the Treadway Commission. (2013, May). Internal Control-Integrated Framework Executive Summary. Retrieved 02.27.15 from www.coso.org. 


\section{TEACHING NOTES}

1. Who are the key actors?

The key actors are:

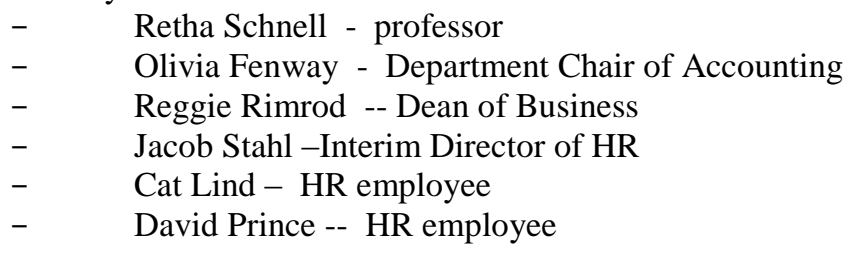

2. a. Who made the first error in signing the PAF?

Dr. Oliva Fenway made the first error by initiating and then signing the PAF; Dr. Schnell was not due to teach again for the department of accounting and yet Dr. Fenway initiated a PAF for Dr. Schnell.

b. Who made the second error in signing the PAF?

Dean Rimrod, who knew Dr. Schnell personally, and knew she had moved to another state, made the second error; he also signed the PAF.

c. When the PAF got the HR, the two personnel there apparently simply signed the form. What should they have done?

The HR personnel who approved the PAF should have compared the PAF to the early retirement paperwork as a control prior to signing (ie approval).

3. a. What is the definition of internal control, per COSO?

Internal control is a process, effected by an entity's board of directors, management, and other personnel, designed to provide reaosonable assurance regarding the achievement of objectives relating to operations, reporting, and compliance.

b. Give the five components of internal control, per COSO.

Control environment

Risk assessment

Control activities

Information and communication

Monitoring

c. The last component of internal control is monitoring. Monitoring may include ongoing evaluations. An example of ongoing evaluations is managers comparing actual results to budget. For example, the Dean (manager) may compare the actual salary results to the budgeted amounts at the end of the semester. Would monitoring have found the pay mistake for Dr. Schnell?

Monitoring may possibly have located the pay mistake. The new Dean took over in August of year 2. Therefore, the new Dean is not as familiar with either the faculty or the reports as one with more experience. The new Dean may not pick up on Dr. Schnell's name appearing on a report listing salary expense for Fall, year 2 when she is not teaching. Further, the new Dean may not have a firm handle on the total amount of salaries to expect. One part-time person's salary may not stick out to the new Dean.

4. a. Was the design of internal control, i.e, the authorizations on the PAF form, adequate?

Yes, the design of the authorizations on the PAF form was adequate.

The Department Head was to authorize, followed by the Dean. Then, in HR, the employee assigned to the 
College was to authorize. Finally, in HR, the employee with payroll functions was to authorize. Four authorizations should be adequate.

b. Was the operation of the internal control of authorization on the PAF form adequate?

Obviously, the operation of this internal control did not work, so no, the operation was not adequate.

The Department Head, who had signed the early retirement paperwork for Dr. Schnell, initiated a PAF for her in error. He forwarded the paperwork on to the Dean. The Dean apparently did not look at the paperwork and simply signed the PAF.

HR had the early retirement paperwork with the indication that Dr. Schnell had chosen to teach one year part-time. Neither Ms. Lind nor Mr. Prince chose to check that paperwork.

Thus, four people authorized the payment of part-time salary for Dr. Schnell for the next academic year when she would not be teaching.

5. Should employee annual evaluations include criteria encompassing whether the employees have adhered to internal controls? In this case, that would be the evaluation of Dr. Fenway, Dean Rimrod, Ms. Lind, and Mr. Prince. In developing your answer, be sure to read number 5. under Control Environment within the Components and Principles section (p. 6) at www.coso.org "Internal Control -Integrated Framework Executive Summary" (2013).

Yes, employee annual evaluations should include criteria encompassing whether the employee, regardless of what level at the organization the individual is at, follows internal control policies and procedures. The annual evaluations of Dr. Fenway, the Department Head in Accounting; the Dean of Business, Dean Rimrod; Ms. Lind in HR; and Mr. Prince, also in HR; should reflect that each authorized payment of salary for a faculty member who was not teaching at the University.

Only by holding individuals accountable for their actions will they take actions to prevent such errors in the future. COSO notes that "the organization holds individuals accountable for their internal control responsibilities in the pursuit of objectives."

Besides the five components of internal control, COSO also presents 17 principles of internal control. Each of the principles is associated with one of the components. The fifth principle reads, "Enforces accountability," and is tied to the Control environment component. The control environment encompasses the board of directors and its establishment of the tone at the top, especially regarding internal control. The fifth principle associated with this component then is emphasizing that the Board must enforce accountability by management. One way to stress the importance of internal controls is to include adherence to internal control policies and procedures on annual evaluations. 


\section{NOTES}

